\title{
International Germ Cell Consensus Classification
}

National Cancer Institute

\section{Source}

National Cancer Institute. International Germ Cell Consensus Classification. NCI

Thesaurus. Code C111073.

A staging system for metastatic malignant germ cell tumors developed by the International Germ Cell Cancer Collaborative Group. It is a factor-based system that produced three prognostic groups; good prognosis, intermediate prognosis, and poor prognosis. 